\title{
ENGO Impacts on Climate Change Policy in European Malta
}

\author{
Michael Briguglio \\ Department of Sociology, University of Malta, Malta
}

Copyright $(2017$ by authors, all rights reserved. Authors agree that this article remains permanently open access under the terms of the Creative Commons Attribution License 4.0 International License

\begin{abstract}
This article analyzes the impacts of ENGOs with respect to Maltese climate change policy in an EU context. In particular, focus is made on the politics of climate change in Malta and the EU in the first five years following the country's EU accession, which led to the setting of energy emissions targets by 2020. The main conclusion of this article is that ENGOs formed part of an EU-wide hegemonic formation on climate change, wherein a common position with binding emissions targets was reached. The common position was signified around the discourse of ecological modernization. EU multi-level governance provided an opportunity for ENGOs to put forward discourses for climate-change adaptation.
\end{abstract}

Keywords Environmental NGOs, Climate Change Politics, EU Governance, Sociology of Climate Change

\section{Introduction}

According to the Intergovernmental Panel on Climate Change (IPCC) [1], Malta is vulnerable to the effects of climate change, for example due to sea-level rise. Economic sectors such as tourism, fishing and public utilities are deemed to be the most vulnerable, even though the country has considerable experience in adaptation to variability in climate.

Yet Malta was a European laggard in sustainable energy policy when the European Union (EU) was discussing its climate change targets for 2020. Malta was on the bottom of the EU list regarding the share of renewable energy within final energy consumption, and it had the highest energy dependency rate in the EU due to its oil imports [2]. Malta's greenhouse gas emissions rose by 49 per cent between 1990 and 2007. At 89 per cent, the energy sector was the highest contributor to greenhouse gas emissions [3].

Within the bigger picture however, Malta was one of the lowest emitters of greenhouses gases in the EU [2], [3]. Even though its share of greenhouses gases was on the increase, this only amounted to 0.1 per cent of the EU total. Malta also had the second highest greenhouse gas emissions per capita in the EU, second only to Cyprus, another small-island member state [2].

This takes us to the scope of this study. This article analyzes the impacts of ENGOs with respect to Maltese climate change policy in an EU context. In particular, focus is made on the politics of climate change in Malta and the EU in the first five years following the country's EU accession, which led to the setting of energy emissions targets by 2020 .

This article focuses specifically on the political processes related to climate change policy, and not on the validity or otherwise of claims on the scientific merits of each policy. Indeed, it is argued that even though environmental concerns such as climate change may factually exist externally to human consciousness, they do not 'constitute themselves as objects outside any discursive conditions of emergence' [4].

The next section will discuss the construction of climate change policy in Malta in relation to its EU accession in 2004.

\section{The Construction of Climate Change Policy in European Malta}

Prior to Malta's EU accession in 2004, climate change was not mainstreamed in Maltese legislation and policy, even if it was Malta's appeal regarding climate change in 1988 that kick-started the process culminating in the Climate Change Convention of the United Nations in 1992 [5], which Malta ratified in 1994.

During this period, calls were being made for Malta's adaptation to climate change. For example, in its report 'Sustainable Malta' [6], Friends of the Earth Malta appealed to the Government of Malta to reduced carbon dioxide emissions by 33 per cent by 2010 and by 79 per cent by 2050 .

This was quite an ambitious demand. Indeed, between 1990 and 2002, energy consumption in Malta grew by 61 per cent [7], and there was no significant infrastructure for renewable energy such as solar and wind energy [8]. 
By the time that Malta became an EU member-state, climate change became a major policy issue. The EU was setting up targets for 2020 and beyond, and ENGOs organized at EU and national levels were mobilizing themselves in this regard.

During 2006 ENGOs organized at an EU level appealed for EU greenhouse emission reductions by at least 30 per cent by 2020 and 80 per cent by 2050 , in order to reach the European Council's goal of keeping global temperature rise below 2 degrees Celsius over pre-industrial levels. They also appealed for a 25 per cent target of renewable energy sources by 2020 , for a reduction of at least 20 per cent of energy consumption by 2020 [9].

When the European Commission (EC) published its green paper on climate change in 2006, it highlighted six priorities which were not as binding and ambitious as those proposed by the ENGOs. Besides, this required addressing global warming, with possible 2020 targets 'in order to provide a stable investment climate to generate more competitive renewable energy in Europe'; the boosting of energy technology to 'ensure that European industries are world leaders', and ensuring that the EU speaks with a common external voice [10].

In the meantime, Malta and some other EU member states were falling back in compliance with the EU legislation ([11], [12], [13]). The European Commission pressurized such countries to conform to EU requirements. This was endorsed by European and Maltese ENGOs, though they believed that it did not go far enough ([14], [15]).

Subsequently, the European Commission launched its new energy policy subject for approval by the Council of Ministers, which, amongst other proposals aimed to cut $\mathrm{CO}_{2}$ emissions by at least 20 per cent by 2020 compared to 1990 levels, with a further increase to 30 per cent should other developed nations comply through an international agreement. This target was way above the 8 per cent Kyoto target that the EU supported in 1997 and which entered into force in 2005. The European Commission also proposed a binding target of 20 per cent renewable energy by 2020 (up from 7 per cent), a 10 per cent target for biofuels for transport, and increased energy efficiency by 20 per cent [16]. Maltese ENGOs and the non-parliamentary Green Party pressured the Maltese Government to support such changes [17].

During 2007, the Environment ministers from the EU member states unanimously backed the proposals of the European Commission. This was applauded by ENGOs [18]. At the same time, various EU member states, including Malta, appealed for concessions on their national share of $\mathrm{CO}_{2}$ reductions, and called for flexibility and for voluntary as opposed to mandatory national targets ([19], [20], [21]).

During the EU summit held in March 2007, the EU leaders upheld the proposals of the European Commission, but also agreed with the proposal of member states including Malta that national targets should vary in accordance with each country's circumstances. However, these targets were to be binding [22].
ENGOs at European and Maltese levels noted the EU-wide agreement, but called for more political will in order to reach the targets, which were lower than what ENGOs demanded ( [23], [21], [24], [25], [26], [27], [28]).

The upcoming United Nations' global summit on climate change was due to be held in Copenhagen during December 2009. The EU was finalizing its climate policy, and ENGOs kept up their activism in this respect [29].

In this context European Commission President Barroso seemed to play the role of arbiter between different positions, when he spoke about 'historic' plans to make the EU 'the first economy for the low-carbon age' in his address to the European Parliament. Barroso said that the Commission's plans were 'not in favor of the environment and against the economy' [23]. The European Parliament backed the plans for an increased use of renewable energy [30].

In the meantime, general elections were held in Malta in March 2008. Climate change was not a key electoral issue, but nevertheless Malta still had to lobby and formulate climate change policy within an EU framework. The centre-right Nationalist Party remained in power, and consequently the new Government set up a committee for climate change. This comprised various representatives from various sectors, including some ENGO members - though not all ENGOs were asked to participate. The committee had to ensure that Malta fulfilled its EU obligations regarding $\mathrm{CO}_{2}$ emissions and alternative energy [31]. Concurrently, various ENGOs presented proposals as to how the Maltese Government could achieve its goals ([32], [33], [34], [35]).

Late in 2008, negotiators from the European Parliament, the European Commission and the member states agreed on a compromise which would establish mandatory targets for member states in order that the EU may achieve the 20 per cent renewable energy target by 2020 . Through the deal, the EU member states would be able to plan joint projects and to transfer renewable energy produced 'statistically' between themselves. The agreement was welcome on the ENGO front, albeit criticized for its loopholes [36], which eventually were exploited by some member states including Malta in their claim for future reviews and fairness among member states ([37], [38]).

The EU eventually finalized its climate deal in December 2008. An agreement on a 20 per cent reduction of $\mathrm{CO}_{2}$ emissions and 20 per cent production of renewable energy was reached. Various compromises were made, resulting in criticism from the ENGOs and greens especially due to the high levels of carbon offsets. As a result of these compromises member states were being allowed to pay for emissions cuts in developing countries rather than in their own respective countries [39].

When the Copenhagen summit eventually took place, the environmental movement was disappointed by its outcome, as it did not result in any clear binding targets [40]. At the same time, however, the EU confirmed its own targets and eventually set up a Directorate General for Climate Action within the European Commission [41]. 
Malta now had to comply with the EU target through which Malta would be required produce 10 per cent of its energy from clean renewable sources by 2020 . This included energy from transport, electricity, heating and cooling [42]. Malta was also obliged to limit $\mathrm{CO}_{2}$ emissions increase by 5 per cent by 2020 and to have 10 per cent biofuel for transport use by 2020 [43]. Malta's targets were the lowest in the EU, even though this presented a significant increase from what was in place. For example, renewable energy accounted for only 0.36 per cent of the country's total energy mix. [44].

The following table highlights major changes in climate change policy-making in the EU and Malta between 2004 and 2009.

\begin{tabular}{|l|}
\hline \multicolumn{1}{|c|}{ Chronology of Climate Change Policy Making in EU and Malta } \\
\hline 2004 Malta joins the European Union \\
\hline 2006 EU ENGOs call for ambitious EU greenhouse emissions \\
\hline $\begin{array}{l}2006 \text { EC publishes green paper on climate change, with less ambitious } \\
\text { targets }\end{array}$ \\
\hline $\begin{array}{l}\text { 2006 Malta and other MS were falling back in compliance with EU } \\
\text { legislation }\end{array}$ \\
\hline 2007 EC launches energy policy subject for approval by ECM \\
\hline 2007 Malta ENGOs pressure Government to support EC proposals \\
\hline 2007 ECM unanimously back EC proposals \\
\hline 2007 Some MS including Malta appeal for concessions and flexibility \\
\hline $\begin{array}{l}2007 \text { EU summit upholds both EC and MS proposals, with varying } \\
\text { national targets }\end{array}$ \\
\hline $\begin{array}{l}2008 \text { EC, EP and ECM agree on compromise deal with varying national } \\
\text { targets }\end{array}$ \\
\hline 2008 EU finalizes its climate deal, in advance of UN summit in 2009 \\
\hline $\begin{array}{l}\text { 2009 UN summit fails to reach binding targets. EU and MS stand by } \\
\text { their respective targets }\end{array}$ \\
\hline
\end{tabular}

\section{Conceptualizing Policy Impacts of ENGOs}

The next sub-sections will provide a theoretical framework through which one can analyze the impacts of ENGOs in relation to climate change policy in European Malta. For this purpose, the concepts of hegemonic formations, substantive impacts and multi-level governance will be discussed. This will be followed by a discussion on major political discourses of climate change.

\section{Hegemonic Formations}

The main thrust of this article is to verify the impact of ENGOs on climate change policy in European Malta. This was achieved by means of an EU-wide general agreement within the EU that represented a condensation of different and often - conflicting claims. Still, the overarching discourse was broad enough to include plural social actors, ranging from Governments to ENGOs, within it. Policy-making was carried out through multi-level governance within European and Maltese levels.
In order to analyze the most influential discourses in this regard, this study draws upon discourse theory ([4], [45], [46], [47], [48], [49]).

In this regard, ENGOs are conceptualized as being active in politics through discursive constructions. Social agents including Governments, European institutions, political parties and forces within civil society engage in articulatory practice and temporarily fix meaning through nodal points [4] comprising empty signifiers which are filled up with discursive claims ([45], [50], [47]).

Here, discursive coalitions are formed between insiders and outsiders, where internal differences are minimized in opposition to the discursive exterior [51]. This means that the commonalities of insiders are emphasized within 'chains of equivalence' [4], where specific demands of social agents are partially surrendered for the greater good. The universal claim that unites its components is greater than particular demands which characterize the individual social agents within it. 'Conflictual consensus' [52] may therefore be in place within chains of equivalence.

In turn, this may give rise to hegemonic formations, where 'privileged condensations of meaning confer partially fixed meaning on a particular set of signifiers' [48]. Diverse democratic demands achieve 'a maximum of integration' Mouffe[4] and are empowered to bring about political and/or social change. At the same time, given that a hegemonic formation excludes other discourses, it can be opposed by counter-hegemonic practices [53].

\section{Substantive Impacts}

This research elaborates on the construction of hegemonic formations by employing the concept of external impacts of social movements ([54], [55], [56], [57]), with particular emphasis on substantive impacts. These can range from

'challengers' ...[ability] ... to exert a veto against a policy or against a decision taken by political authorities... [to the ability to] ... obtain substantive concessions by political authorities. In this case, they acquire policy-making power' ( [54]).

Further examples may include decisive decisions by the State, the setting up of legislation and enforcement measures. In this respect, environmental movements do not usually obtain too many substantive impacts [55]. One exemption may be within certain local issues [57], but these 'have rarely proved decisive in the wider policy arena' [56]. Besides, Carter makes it clear that the mainstream environmental movement has experienced primarily from a 'negative' substantive impact, wherein in does not manage to change policy discourses.

The concept of substantive impacts can help elaborate the analysis of hegemonic formations as it is hereby argued that success and failure can co-exist in a paradoxical relationship. For example environmental movements can influence policy making whilst being less successful in halting the 
deterioration of the environment [58]. In the specific context of this study, a hegemonic formation on climate change may be partially satisfying for environmentalists but might still not be considered sufficient to halt consequences of climate change on the natural environment.

\section{Multi-level Governance}

This article also draws upon literature concerning multi-level governance so as to conceptualize the interaction between national and European politics and activism of ENGOS in this regard.

Literature on social movements and European environmental politics has suggested that research in this area should focus on different geographical areas at the same time, or 'multi-level activism' Heijden [29]. At the same time, research on the Europeanization of environmental policy can focus on 'both the shaping and taking of EU policies' [59].

According to van Der Heijden [29], 'the EU's most important feature is its evolution into a system of multi-level governance as opposed to state-led government.' (p.5). It turn, multi-level governance is defined as 'the dispersion of authoritative decision making across multiple territorial levels' [60].

Within multi-level governance, national governments do not possess a monopoly of power, but have to share decision-making with other actors at different levels. In an EU context, this form of governance is characterized by a dispersion of competencies, interlocking institutions and shifting agendas Heijden [29].

Climate change policy is an example of multi-level governance and environmentalism (ibid, p.200) within national, EU and global contexts. Indeed the global climate campaign under study comprised various environmental movement organizations and illustrates the evolution of one 'global green public sphere (ibid p. 197). This points towards the importance of systematic study of environmental movements 'at different geographical levels at the same time' (ibid)

Tanya Börzel [59] adds that ENGOs coming from Southern European countries are most likely to benefit from opportunities provided by the EU which can be used to put pressure on their respective governments, are at the same time most likely to take advantage of them, given their lack of resources. Social actors who do not exploit resources to their advantage on the international level are likely to be weakened, due to the fact that much environmental policy is being carried out beyond the nation state.

Multi-level governance and activism is of particular interest for this article. The EU is conceptualized as a possible gateway through multi-level governance, enabling ENGOs at European and national levels to have impacts on policy-making.

\section{Discourses of Climate Change}

Another key concept used in this study relates to the construction of discourses of climate change within EU policy-making.

Scholarly literature relates EU environmental policy to the discourses of sustainable development and ecological modernization ([61], [62], [63]) albeit within a context of strong neo-liberal tendencies (Pesendorfer[64], van der Heijden [29]). Radical discourses of system change are not so influential within an EU context ([65], [66]).

Sustainable development attempts to reconcile economic, social and environmental factors through the involvement of the State and civil society by means of cooperation at international, national and local levels [67]. It is enshrined in the treaties of the EU, but the predominant way how it is articulated is through the discourse of ecological modernization ([29], [62]).

Ecological modernization, promotes environmentally sound technological development within highly industrialized societies having democratic institutions. A main feature of this discourse is the belief that economic growth and environmental protection can complement each other within existing political, social and economic structures ( [56], [68], [69] [67]). According to Hajer [29], ecological modernization can be described as a discourse coalition between business, scientists, reformist progressive politicians and much of the environmental movement.

Ecological modernization can be summed up as follows:

\begin{tabular}{|c|}
\hline Ecological Modernization \\
\hline Technological \\
\hline Economic and environmental complementation \\
\hline Reformist \\
\hline
\end{tabular}

At a European level, ENGOs have formed coalitions such as Green 10, which is characterized by moderate environmental discourse when dealing with climate change issues [66] and the Spring Alliance, which has challenged the 'neo-liberal European Union policy frame' [29].

Some European ENGOs have their own Maltese counterparts - such as Birdlife and Friends of the Earth. Malta also has a Green Party which has been elected in some local councils but which has considerable presence in Malta's public sphere. Overdevelopment of land and conservationism are major preoccupations of environmentalists and moderate discourses are predominant ([70], [71]). ENGOs are largely active in a context of two-party dominance ([72], [73]), even though, following EU accession, the Maltese Government 'cannot unilaterally craft legislation that has clear implications on the other member states of the EU, and on the EU itself' [74].

\section{Research Question and Methods}

In view of the literature presented above, this article seeks to answer the following research question:

What were the impacts of ENGOs with respect to Maltese 
climate change policy in an EU context?

For the purpose of this study, the main concepts referred to previously were operationalized in relation to the construction of climate change policy in Malta within an EU context.

The main discourses under analysis were identified through data in textual form. Data for this study was primarily obtained from one Maltese newspaper, the English-speaking daily newspaper 'Times of Malta' and its sister newspaper 'The Sunday Times of Malta'. These are Malta's best-selling newspapers and they have a long tradition in journalism since the 1930s. They also have a very strong online presence. Allied Newspapers, which publishes The Times of Malta, has been described as 'an institution in itself' [75].

Twenty seven news articles for the period 2006-2009 and which were related to Malta's climate change policies in an EU context were collected and analyzed for this purpose. These were supplemented by other news articles during this period from international news agencies, namely Reuters (through its Planet Ark website) (8 articles), Euractiv.com (8 articles) and EUobserver.com (4 articles).

All articles were collected systematically through regular screening of news items dealing with the interaction of EU policy on climate change with environmental activism and/or Maltese policy-making. Data was coded in a qualitative manner, where the emphasis was on strategic importance of discursive threads and key events rather than quantitative presence of data. For example, a statement resulting from an EU summit might have been produced once, yet its strategic effect is of prime significance in view of its influence on policy making. Hence, collection of information from newspapers and other documents involved the unearthing of 'essences with sufficient context' [76], where even 'a single speech or newspaper report or conversation can generate very fruitful themes for analysis' [77].

Commonalities and differences in discourses of ENGOs, EU institutions, national governments and other social actors were highlighted, so as to identify the existence of discourse coalitions that were signified through nodal points and chains of equivalence. Consequently, it was possible to verify whether a hegemonic formation was formed, and if yes which discourses were included within it.

In particular, the following discourses were sought for:

- Radical: Need for system change

- Ecological Modernization: Need for stronger obligatory targets across the EU

- Ecological Modernization: Need for voluntary targets on a national level

- Ecological Modernization: Need for weaker obligatory targets across the EU

- Discursive exterior: No need for change.

These discourses were analyzed in relation to van Der Heijden's [29] assertion that within the EU sustainable development is seen as being framed through ecological modernization, 'the discourse that recognizes the structural character of environmental problems, but nevertheless assumes that existing political, economic and social institutions can internalize care for the environment' (p.197).

Hence ecological modernization occupied the role of nodal point. The social actors which were analyzed were EU institutions, the Government of Malta, European and Maltese ENGOs. Occasional reference was also made to business representatives on an EU level as well as political parties.

It is important to note that the Maltese ENGOs which spoke up on climate change were generally active on a national level, though they relied on the lobbying of European ENGOs at an EU level. The discursive constructions of the latter as reported in the media were therefore given due importance in this study.

In the case of Friends of the Earth Malta, its activism was integrated with that of its European counterparts. For example, as the United Nations' global summit on climate change in Copenhagen, held in December 2009, was approaching, it participated with other national branches of Friends of the Earth International during the Global Day of Action on Climate activities [29].

Discourse analysis was applied in relation to the positions of social actors with relation to the nodal point of ecological modernization and the way this was signified through their discourses. If a substantive impact was achieved through policy change, and if this had some form of consensus around it, then a hegemonic formation was seen to be constructed.

\section{Results}

The results of this research show that the most influential discourse at EU level was that of ecological modernization which would be implemented through weaker obligatory targets across the EU. This discourse was particularly suitable for Malta, given its lack of a climate change policies and its need to catch up with many other EU member states. This discourse was also more likely to reach support across the political and civil society spectrum within the EU.

Specific analysis of each discourse produced the following results:

\section{- Radical: Need for System Change}

This radical discourse was generally not favored by ENGOs. The only Maltese exception was Zminijietna Voice of the Left, which considered the EU proposals to be situated within

'a capitalist framework of endless production, commodification and technological quick-fixes, which, ultimately, do not solve the problems of wasteful consumption and social inequality' [26].

At this time, Zminijietna also had an antagonistic approach on the EU treaty, considering it to be a neo-liberal 
imposition with profound implications. Zminijietna's stance on the EU treaty was not in conformity with that of other ENGOs. Indeed, EU ENGOs such as the European Environmental Bureau [78], on behalf of 143 ENGOs, were rather upbeat about it, and praised aspects such as democratization and transparency.

- Ecological Modernization: Need for Stronger Obligatory Targets across the EU

This discourse comprised the main arguments put forward by ENGOs at a European level, and which was supported by Maltese ENGOs. During 2006, ENGOs organized at an EU level appealed for EU greenhouse emission reductions by at least 30 per cent by 2020 and 80 per cent by 2050 , in order to reach the European Council's goal of keeping global temperature rise below 2 degrees Celsius over pre-industrial levels. They also appealed for a 25 per cent target of renewable energy sources by 2020 , for a reduction of at least 20 per cent of energy consumption by 2020 , which could save 60 billion Euros per year and create 'as many as 1 million new jobs' [9]. This approach was reformist and focused on technological change.

In this regard, WWF [28] claimed that climate change is happening faster than predicted, with huge adverse risks in various sectors - from food to health - in the pipeline.

The Green 10 [79] alliance of European ENGOs used consensual rhetoric by appealing to the European Commission to match green rhetoric with action by recognizing that the environment and the economy can be complimentary. With respect to greenhouse gas reductions the European Environment Bureau and the European Trade Union Confederation called for tax adjustments so as to protect EU-based industry from 'unfair competition' [29].

In Malta, ENGOs [17] supported the calls of their European counterparts, but also called for the Maltese Government to support the EU in the implementation of the Kyoto targets and in post-Kyoto discussions especially when Malta was a laggard in policies such as investment in renewable energy. Nature Trust [27], Moviment Graffitti [27], Din 1-Art Helwa [32] all called for increased investment in renewable energy.

The discourses of Maltese ENGOs were not without their own antagonisms, however. For example, when the Government of Malta earmarked a particular site for offshore wind farms, Birdlife Malta and Bicref expressed their opposition through conservationist claims in view of bird colonies in a nearby Natura 2000 site and in view of marine ecosystems. Bicref[80] said that solar energy should be considered before other options.

All in all, European and Maltese ENGOs signified ecological modernization through technological change, reformist policy, and complementation of environmental and economic factors.

- Ecological Modernization: Need for Voluntary Targets on a National Level

An alternative discourse of flexible targets was promoted by national governments and business representatives. This contrasted with the demands of the environmental movement, even though it recognized the need for reform, technological change and possible complementation of economic and environmental factors.

When in 2007 environment ministers from EU member states unanimously backed the proposals of the European Commission, it transpired that antagonistic political demands were being articulated, both by national governments and business representatives. Various Ministers, including Malta's appealed for EU concessions on greenhouse gas reductions and for voluntary - rather than mandatory - national targets [19]. Prior to the European Council meeting that dealt with the matter, Prime Minister Lawrence Gonzi said:

'We can't have hydroelectric power as we have no rivers or dams. We can't have the amount of photovoltaic energy we would like to as our land is not big enough to have the necessary plants installed. So we need to be realistic. A one size fits all policy in this sector is not ideal' [20].

Malta had also unsuccessfully asked for an annual allocation of greenhouse gas emissions which exceeded that eventually demanded by the European Commission [22], [81]. On the other hand, the Government of Malta [22] welcomed this proposal to have national targets vary within a European framework, as will be discussed below.

When the EU adopted its climate change deal, Business Europe pronounced its discourse for flexibility, by stating that

'the deal would still impose higher costs on companies, particularly SMEs, in the form of higher energy and $\mathrm{CO}_{2}$ prices and a greater administrative burden' [82].

- Ecological Modernization: Need for Weaker Obligatory Targets across the EU

The fourth discourse was the most influential discourse at EU level. There was agreement with the claims made by ENGOs for binding targets, yet they were weaker, and national variations were put in place, depending on the country in question.

A relatively early important pointer in this regard was put forward by the European Commission [10] in 2006, when it highlighted its plans to address global warming by boosting clean energy and having a common external voice.

The European Commission's proposal [16] included the need to cut greenhouse gas emissions by at least 20 per cent by 2020 compared to 1990 levels, with a further increase to 30 per cent should other developed nations comply through an international agreement. European and Maltese ENGOs welcomed the EC's stance, but it was considered as not going far enough, and in the Maltese case, ENGOs ([14], [15]) expressed concern with the need for increased investment and drive from the Government. Indeed, according to the European Environmental Agency [34], unlike other 
Mediterranean countries which have 'quite extensive climate change assessments', Malta had to date not yet prepared a plan on how to adapt to climate change.

Late in 2008, negotiators from the European Parliament, the European Commission and the member states agreed on a compromise which would establish mandatory targets for member states in order that the EU may achieve the 20 per cent renewable energy target by 2020 . Through the deal, the EU member states would be able to plan joint projects and to transfer renewable energy produced 'statistically' between themselves. Greenpeace hailed the agreement as a

'ray of light... [a] sunny spell before heavy showers, as European leaders create loophole after loophole in other parts of the EU's package of laws to tackle climate change' [36].

When the EU finalized its climate deal in December 2008, in advance of the Copenhagen summit, the agreement on a 20 per cent reduction of $\mathrm{CO}_{2}$ emissions and 20 per cent production of renewable energy was adopted. Various compromises were made, resulting in criticism from ENGOs and Greens especially due to the high levels of carbon offsets. As a result of these compromises member states were being allowed to pay for emissions cuts in developing countries rather than in their own respective countries (Harrison and Jones [39]). For example, Greenpeace stated that the deal did not guarantee an EU emissions reduction of 20 per cent, let alone the required 30 per cent which was really needed as a bare minimum against global warming.

The European Peoples' Party and the European Liberals welcomed the deal. The European Photovoltaic Industry Association [82] was positive too, though critical on certain exemptions and Business Europe [83] lamented on higher costs and administrative burdens, especially on Small and Medium Enterprises. Yet the latter would probably have been even more critical if stronger targets were adopted by the EU.

At a global level, and in comparison to what was proposed at the eventual global summit on climate change in Copenhagen, the EU's position was tougher than that of other blocs around the world. At the same time, however, the EU adopted a weak position in the summit, Commenting on this, Nature Trust said that

'it is ironic that while civil society and environmental NGOs seem to be greatly concerned on our future, some world leaders are simply coming up with excuses' [40].

In such a context, the EU position characterized by binding targets was a significant step forward on a global level. Notwithstanding the Copenhagen flop, there was a substantive impact on Malta's policies regarding climate change. The Government of Malta had to comply with the EU target through which Malta would be required produce 10 per cent of its energy from clean renewable sources by 2020. Malta was also obliged to limit $\mathrm{CO}_{2}$ emissions increase by 5 per cent by 2020 [43]. Malta's clean energy targets were the lowest in the EU, even though this presented a significant increase from the then current 0.36 per cent [84].

\section{- Discursive Exterior: No Need for Change}

The fifth discourse was used by the environmental movement as a discursive exterior Mouffe [4] so as to help ensure that the EU does not renege on its commitment to reduce dependency on fossil fuels.

Here ENGOs appealed for the phasing of subsidies to fossil fuels and opposed nuclear energy on environmental and economic grounds. ENGOs also complained that the European Emissions Trading Scheme was too generous, as it rewarded the worst polluters in the EU. According to WWF, the EU was handing 'free pollution permits... [which].. is like handing them a cash bonus' ([14], [85]).

\section{Discussion and Conclusions}

The results of this study show that EU provided political opportunities for ENGOs in relation to the construction of climate change policy within a framework of multi-level governance.

Indeed, 'climate change has become an important driver of European integration in general, as it increases the EU's domestic legitimacy' [29].

In the process, ecological modernization was the dominant discourse in terms of policy. It emphasized the reaching of targets technology, policy reform and complementation of economic and environmental factors.

The signifier which called for a reduction in greenhouse gas emissions formed a nodal point ([4], [47]). The chain of equivalence for compulsory adaptation within the EU prevailed, albeit through weaker targets than those demanded by ENGOs.

The EU therefore adopted a deal which condensed the various antagonisms represented by different discourses. The EU-wide compromise position constructed a broad hegemonic formation.

As suggested by Laclau and Mouffe [4] in their theoretical analysis of hegemonic formations, specific political demands, such as those of ENGOs partially surrendered some of their claims, but ultimately conceded that a common position on climate change within the EU was better than not having a deal. In this respect, adaptation to climate change became mainstreamed in EU policy, in spite of the resistance of various national governments and business interests. The EU was ultimately characterized by 'conflictual consensus' [52]

Consequently, policy and legislative changes took place at EU level, resulting in binding targets for each member state within an EU framework.

Malta's climate change policy was constructed within this context. From a country being devoid of energy policies in relation to climate change, it was now bound by targets. Maltese ENGOs and their European allies within the broader environmental movements made use of European political 
opportunities were successful in implementing substantive policy change.

\section{REFERENCES}

[1] Mimura N, Nurse L, McLean RF, Agard J, Briguglio L, Lefale P, Payet R, and Sem G. Small islands. In: Parry ML, Canziani OF, Palutikof JP, van der Linden PJ and Hanson CE (eds). Climate Change 2007: Impacts, Adaptation and Vulnerability. Contribution of Working Group II to the Fourth Assessment Report of the Intergovernmental Panel on Climate Change. Cambridge: Cambridge University Press, 2007, pp. 687-716.

[2] Eurostat. Europe in figures. Eurostat yearbook 2010. Luxembourg: Publications Office of the European Union, 2010 .

[3] Malta Environment and Planning Authority (MEPA). The Environment Report Indicators 2008. Malta: MEPA, 2010b.

[4] Laclau E and Mouffe C. Hegemony and Socialist Strategy: Towards A Radical Democratic Politics. London: Verso, 1985.

[5] Hoffmann M. Ozone Depletion and Climate Change Constructing a Global Response. Albany: State University of New York Press, 2005.

[6] Ragonesi R, Manduca J, Mallia EA, and Camilleri M. Towards Sustainable Europe Sustainable Malta - A discussion paper. Malta: Moviment ghall-Ambjent - Friends of the Earth (Malta), 1997.

[7] National Statistics Office (NSO). Environment Statistics. Malta: National Statistics Office, 2006.

[8] Government of Malta. Malta National Report - Submitted by the Government of Malta to the World Summit on Sustainable Development - Johannesburg 2002. Malta: Government of Malta, 2002.

[9] Greenpeace, WWF, European Federation for Transport and Environment, Friends of the Earth Europe \& Climate Action Network Europe. Commission Green Paper on an integrated energy policy for Europe. Letter to European Commissioner Barroso, 2006.

[10] Reuters. Factbox - Proposals for a Common EU Energy Policy, http://www.planetark.com/dailynewsstory.cfm/newsid/35560/ story.htm (9 March 2006, accessed 9 February 2017).

[11] Camilleri I. Malta still not compliant with EU emissions scheme. Times of Malta, 20 May 2006.

[12] Spongenberg H. Brussels takes legal action against 15 member states. http://euobserver.com/9/22190 (31 July 2006, accessed 9 February 2017).

[13] Reuters. EU Takes Action over Climate, Landfill Failures, http://www.planetark.com/dailynewsstory.cfm/newsid/41027/ story.htm (23 March 2007, accessed 9 February 2017).

[14] Mahoney H. EU toughens up on $\mathrm{CO}_{2}$ emissions curbs, http://euobserver.com/9/22979 (29 November 2006, accessed 9 February 2017).

[15] Times of Malta. Praise for green initiatives. http://www.timesofmalta.com/articles/view/20060606/local/p raise-for-green-initiatives.51682 (6 June 2006, accessed 9 February 2017).

[16] Reuters. Factbox - Main Points of New EU Energy Strategy. http://www.planetark.com/dailynewsstory.cfm/newsid/39791/ story.htm (11 January 2007, accessed 9 February 2017).

[17] Times of Malta. Bastion lights switched off to mark Kyoto Treaty anniversary. http://www.timesofmalta.com/articles/vie w/20070217/local/bastions-lights-switched-off-to-mark-kyoto -treaty-anniversary.26253 (17 February 2007, accessed 9 February 2017).

[18] Reuters. EU Backs Bold Climate Change Goals. http://www.planetark.com/dailynewsstory.cfm/newsid/40425/ story.htm (21 February 2007, accessed 9 February 2017).

[19] Camilleri I. Final decision to be taken by EU leaders. $\mathrm{http} / /$ www.timesofmalta.com/articles/view/20070306/local/fi nal-decision-to-be-taken-by-eu-leaders.24453 (6 March 2007, accessed 9 February 2017).

[20] Camilleri I. EU leaders to decide on crucial climate change targets.

http://www.timesofmalta.com/articles/view/20070309/local/e u-leaders-mto-decide-on-crucial-climate-change-targets. 2413 7 (9 March 2007, accessed 9 February 2017).

[21] Euractiv.com. Environment ministers favor flexible EU climate action.http://www.euractiv.com/climate-change/envir onment-ministers-favour-fle-news-219477. (4 March 2008, accessed 9 February 2017).

[22] Camilleri I. EU sets tough energy targets. http://www.timesofmalta.com/articles/view/20070310/local/e u-sets-tough-energy-targets.24048 (10 March 2007, accessed 9 February 2017).

[23] BBC News.. EU reveals energy plan of action. http://news.bbc.co.uk/2/hi/7203514.stm (23 January 2008, accessed 9 February 2017).

[24] Mizzi C. Nuclear power costly and toxic. www.timesofmalta.com/articles/view/20080201/letters/nucle ar-power-costly-and-toxic (1 February 2008, accessed 9 February 2017).

[25] Times of Malta. Friends of the Earth on alternative energy sources.

http://www.timesofmalta.com/articles/view/20070313/local/fr iends-of-the-earth-on-alternative-energy-sources.23665 (13 March 2007, accessed 9 February 2017).

[26] Times of Malta. Climate change requires realism, leftist NGO insists.

http:/www.timesofmalta.com/articles/view/20080204/local/c limate-change-requires-realism-leftist-ngo-insists.194977 (4 February 2008, accessed 9 February 2017).

[27] Times of Malta. Call for clean energy strategy. timesofmalta.com. http://www.timesofmalta.com/articles/vie w/20080422/local/call-for-clean-energy-strategy (22 April 2008, accessed 9 February 2017).

[28] Vucheva E. Climate change outracing EU targets, WWF warns. http://euobserver.com/9/26962 (20 October 2008, accessed 9 February 2017).

[29] van der Heijden, H. Social Movements, Public Spheres and the 
European Politics of the Environment. Green Power Europe? Hampshire: Palgrave Macmillan, 2010.

[30] Euractiv.com. MEPs give major boost to renewables industry. http://www.euractiv.com/energy/meps-give-major-boost-rene wables-industry/article-175296 (12 September 2008, accessed 9 February 2017).

[31] Times of Malta. Climate change committee appointed. http://www.timesofmalta.com/articles/view/20080617/local/c limate-change-committee-appointed (17 June 2008, accessed 9 February 2017).

[32] Bianchi P. First and last on climate change. Malta Today. 20 July 2008.

[33] Calleja C. Labour presents climate change Bill. http://www.timesofmalta.com/articles/view/20081011/local/1 abour-presents-climate-change-bill (11 October 2008, accessed on 9 February 2017).

[34] Muscat C. Malta failing in climate change preparation. www.timesofmalta.com/articles/view/20081109/local/malta-f ailing-in-climate-change-preparation-EEA (9 November 2008 , accessed on 9 February 2017)

[35] The Today Public Policy Institute Towards a low carbon society: The nation's health, energy security and fossil fuels. Malta: The Today Public Policy Institute, 2008.

[36] Phillips L. Greens hail EU deal on renewable energy. http://euobserver.com/19/27269 (9 December 2008, accessed on 9 February 2017)

[37] Harrison P. EU Ends Biofuel Battle to Get Green Energy Deal, http://www.planetark.org/wen/50796 (5 December 2008, accessed on 9 February 2017).

[38] Reuters. Malta Wants To Join Rich Nations In Climate Fight http://www.planetark.com/wen/50861 (11 December 2008, accessed 9 February 2017).

[39] Harrison P. and Jones H. EU Finalises Deal To Fight Climate Change. http://www.planetark.org/wen/50953 (18 December 2008, accessed 9 February 2017).

[40] Times of Malta. Nature Trust disappointed at climate summit outcome

http://www.timesofmalta.com/articles/view/20091226/local/n ature-trust-disappointed-at-climate-summit-outcome. 287314 (26 December 2009, accessed 9 February 2017).

[41] European Commission Climate Action. What we do http://ec.europa.eu/dgs/clima/mission/index_en.htm (Accessed 3 March 2012).

[42] Malta Environment and Planning Authority (MEPA) The Environment Report 2008. Malta: MEPA, 2010

[43] Official Journal of the European Union. Decision No 406/2009/EC of the European Parliament and of the Council of 23 April $2009 \mathrm{http}: / /$ eur-lex.europa.eu/LexUriServ/LexUri Serv.do?uri=OJ:L:2009:140:0136:0148:EN:PDF (5 June 2009, accessed on 9 February 2017).

[44] Camilleri I. Ambitious targets for Malta. http://www.timesofmalta.com/articles/view/20080124/local/a mbitious-targets-for-malta.193174 (24 January 2008, accessed on 9 February 2017)

[45] Laclau E. On Populist Reason. London: Verso, 2005.
[46] Laclau E. The Rhetorical Foundations of Society. London: Verso, 2014

[47] Howarth D. and Stavrakakis Y. Introducing discourse theory and political analysis. In: Howarth D, Norval AJ and Stavrakakis Y (eds) Discourse Theory and Political Analysis: Identities, Hegemonies and Social Change. Manchester: Manchester University Press, 2000, pp. 1-23.

[48] Howarth D. Discourse. Milton Keynes: Open University Press, 2000

[49] Howarth D. Applying Discourse Theory: The Method of Articulation. In: Howarth D and Torfing J (eds) Discourse Theory in European Politics - Identity, Policy and Governance. Hampshire: Palgrave Macmillan, 2005, pp. 316-349.

[50] Laclau E. Emancipation(s) (Phronesis S.). London: Verso, 1996.

[51] Griggs S. Problematizing the Mobilization of Hospital Directors. In: Howarth D and Torfing J (eds) Discourse Theory in European Politics - Identity, Policy and Governance. Hampshire: Palgrave Macmillan, 2005, pp. 117-138.

[52] Mouffe C. The Democratic Paradox. London: Verso, 2000.

[53] Mouffe C. On the Political. London: Routledge, 2005.

[54] Giugni M. Outcomes of New Social Movements. In Kriesi H, Koopmans R, Dvendak J and Giugni M (eds) New Social Movements in Western Europe. London: UCL Press, 1995, pp. 207-237.

[55] van der Heijden H. Environmental Movements, Ecological Modernization and Political Opportunity Structures. In: Rootes C. (ed) Environmental Movements: Local, National and Global. London: Frank Cass Publishers, 1999, pp.199-221.

[56] Carter N. The Politics of the Environment - Ideas, Activism, Policy. Cambridge: Cambridge University Press, 2001.

[57] Rootes C. Environmental Movements. In: Snow DA, Soule SA and Kriesi H (eds) The Blackwell Companion to Social Movements. Malden: Blackwell Publishing, 2007, pp. 608-640.

[58] Flesher Fominaya C. Social Movements and Globalization. Hampshire: Palgrave Macmillan, 2014.

[59] Börzel TA. Environmental Policy. In: Graziano P. and Vink MP (eds) Europeanization - New Research Agendas (226-238). Hampshire: Palgrave Macmillan, 2008, pp.226-238.

[60] Delanty G and Rumford C. Rethinking Europe-Social Theory and the implications of Europeanization. London: Routledge, 2005.

[61] Jordan A. Editorial Introduction: The Construction of a Multilevel Environmental Governance System. Environment and Planning C: Government and Policy 1999; 17(1): 1-17.

[62] Baker S. Sustainable Development as Symbolic Commitment: Declaratory Politics and the Seductive Appeal of Ecological Modernization in the European Union. Environmental Politics 2007; 16(2): 297-317. 
[63] Janicke M. Ecological modernisation: new perspectives. Journal of Cleaner Production 2008; 16: 557-565.

[64] Pesendorfer D. EU Environmental Policy under Pressure: Chemicals Policy change between Antagonistic Goals? Environmental Politics 2006; 15(1): 95-114.

[65] Hunold, C. Green Political Theory and the European Union: The Case for a Non-integrated Civil Society. Environmental Politics 2005; 14(3): 324-343.

[66] Briguglio M, Brown M and Bugeja I. ENGO Activism in the EU: The G20, Climate Change and Social Policy. In: Fitzpatrick T (ed) International Handbook On Social Policy And The Environment. Cheltenham: Edward Elgar Publishing, 2014, pp. 176-204.

[67] Sutton PW. Nature, Environment and Society. New York: Palgrave Macmillan, 2004.

[68] Mol APJ and Sonnenfeld DA. Ecological Modernization Around the World: An Introduction. Environmental Politics 2000; 9(1): 3-16.

[69] Milanez B and Buhrs T Marrying strands of Ecological Modernization: A proposed framework. Environmental Politics 2007; 16(4): 565-583.

[70] Briguglio M. Are ENGOs empowered through EU accession? The case of Maltese ENGOs. International Journal of Green Economics 2010; 4(3): 262-274.

[71] Briguglio M. ENGOs, EU accession and empowerment: the case of land rationalization in Malta. International Journal of Green Economics 2012; 6(3): 279-297.

[72] Boissevain J. Saints and Fireworks - Religion and Politics in Rural Malta. Malta: Progress Press, 1993.

[73] Baldacchino G. The Nationless State? - Malta, National Identity and the European Union. West European Politics 2002; 25(4): 191-206.

[74] Baldacchino G. Malta Transformed by Multi-level Governance: More than just an Outcome of Europeanization. Institute of European Studies, http://www.um.edu.mt/_data/ assets/pdf_file/0019/228151/Godfrey_Baldacchino_final.pdf (2014, accessed on 9 February 2017).

[75] Sammut C Reassessing the Maltese media system. In: Cutajar
$\mathrm{J}$ and Cassar G (eds) Social Transitions in Maltese Society. Malta: Agenda, 2009 pp. 75-99.

[76] Wolcott HF. Writing up Qualitative Research. Sage University Series of Qualitative Research Methods, Vol. 20. Thousand Oaks, CA: Sage, 2001

[77] Tonkiss F. Analysing Discourse. In Seale C (ed) Researching Society and Culture. London: Sage, 1998, pp. 245-260.

[78] Euractiv.com. Activists see new lobbying prospects in EU Treaty. http://www.euractiv.com/section/public-affairs/news/ activists-see-new-lobbying-prospects-in-eu-treaty $\quad(2007$, accessed 9 February 2017).

[79] Reuters. EU Puts Money Over Environment - Campaigners. http://www.planetark.com/dailynewsstory.cfm/newsid/41603/ story.htm (2007, accessed 9 February 2017)

[80] Times of Malta. Offshore wind farms, oil drilling 'could impact marine ecosystem'. http://www.timesofmalta.com/arti cles/view/20081029/local/offshore-wind-farms-oil-drilling-co uld-impact-marine-ecosystem (2008, accessed 9 February 2017).

[81] Camilleri I. EU cuts Malta's emissions allocation. http://www.timesofmalta.com/articles/view/20061130/local/e u-cuts-maltas-emissions-allocation.33737 (2006, accessed 9 February 2017).

[82] Euractiv.com.Parliament calls for EU climate change diplomacy.

http://www.euractiv.com/section/development-policy/news/p arliament-calls-for-eu-climate-change-diplomacy/) (2009, accessed 9 February 2017).

[83] Euractiv.com. Mixed reactions as Parliament approves EU climate deal.http://www.euractiv.com/climate-change/mixedreactions-parliament-appro-news-221016 (2008, accessed 9 February 2017)

[84] Camilleri I Ambitious targets for Malta. http://www.timesofmalta.com/articles/view/20080124/local/a mbitious-targets-for-malta (2008, accessed 9 February 2017)

[85] Phillips L. Emissions trading given EU power companies huge windfall profits. Retrieved fromhttp://euobserver.com/9/2593 2 (2008, accessed 9 February 2017). 